\title{
O Livro llustrado como Possibilidade Narrativa
}

PIOVESAN, Jacson; Graduando em Design Gráfico; UFPEL

Orientadora: HERZOG, Vivian; Mestra; UFPEL

Palavras-chave: Livro llustrado; Semiótica; Narrativa

Resumo: No presente texto são discutidos e relacionados alguns conceitos sobre a narrativa com o intuito de colocar o livro ilustrado não como um gênero literário, mas sim como um modo narrativo. Partindo de autores como Linden (2011) Nikolajeva e Scott (2011), Lee (2012) e Antonio Vicente Pietroforte (2005) apresento e relaciono os conceitos de narrativa, com uma pequena reflexão sobre o livro ilustrado. 


\title{
O Livro Ilustrado como Possibilidade Narrativa
}

Para compreender o livro ilustrado como possibilidade narrativa, é preciso compreender a narrativa e o percurso gerador de sentido que acontece nela. Pietroforte (2005) apresenta uma dentre as diversas visões semióticas, baseado nos estudos de Algidar Julien Greimas, servindo de base para este trabalho com o objetivo de compreender alguns conceitos que auxiliam na percepção da narrativa e de sua organização lógica.

\begin{abstract}
A semiótica estuda a significação, que é definida no conceito de texto. O texto, por sua vez, pode ser definido como uma relação entre um plano de expressão e um plano de conteúdo. O plano de conteúdo refere-se ao significado de um texto, o seja, [...] ao que o texto diz e como ele faz para dizer o que diz. O plano da expressão refere-se à manifestação desse conteúdo em um sistema de significação verba, não-verbal ou sincrético. (PIETROFORTE, 2005, p. 11)
\end{abstract}

Pietroforte (2005) também explica que: "O sentido é definido pela semiótica como uma rede de relações, o que quer dizer que os elementos do conteúdo só adquirem sentido por meio das relações estabelecidas entre eles" (p.12,13). O processo gerativo de sentido se dá em um percurso que vai do simples e abstrato ao complexo e concreto. Ele divide o plano do conteúdo dos textos em três níveis: o nível fundamental, que pode ser entendido a partir do exercício de reduzir uma narrativa a uma oposição fundamental, como vida contra morte. O nível narrativo onde os elementos das oposições são assumidos como valores para o sujeito e circulam entre os sujeitos, graças a ações dos sujeitos. E por fim temos o nível discursivo, onde a enunciação se organiza com relação a ao espaço, ao tempo e às pessoas gramaticais. (PIETROFORTE, 2005) (GOMES; MANCINI, 2007).

Quando o plano da expressão deixa de ser apenas uma forma de veiculação de conteúdo e passa a fazer sentido por si próprio, tendo elementos plásticos articulados dentro de uma oposição semântica adicionando mais uma camada de significados a um texto. O plano da expressão e o plano do conteúdo passam, através da relação entre si, a gerar também um significado. Pietroforte (2005) denomina esta relação de semissombilismo. 
Ao observar a narrativa a partir da perspectiva semiótica de Pietroforte (2005), é possível compreender as construções de significado através das relações entre os signos, sejam eles verbais ou não. Assim como é possível perceber que as variações nas articulações desses signos trazem diferentes conotações para seus significantes e que existem possibilidades de variação no sentido que se constrói na leitura, pois o processo de geração de sentido depende não apenas das articulações do enunciante, como também do entendimento do enunciatário.

A narrativa se da em um processo de transformações de relações entre sujeitos e objetos - que podem ser qualquer coisa dotada de um valor positivo ou negativo para o sujeito. Este processo se dá através da articulação dos elementos que permitem expressar um certo sentido, uma sensação qualquer. Nos livros ilustrados, o plano da expressão geralmente se utiliza tanto da linguagem verbal, quanto da linguagem visual para gerar sentido e construir suas narrativas.

O livro ilustrado, diferente dos livros com ilustração - obras onde a ilustração apenas acompanha um texto, é uma obra onde as imagens ocupam não apenas um espaço físico maior, mas também são partes da narrativa. Constituindo não um gênero, já que são diversos os gêneros literários presentes em livros ilustrados, mas um tipo específico de expressão, que une diferentes tipos de linguagem para cumprir o seu papel (LINDEN, 2011).

Por fim, segundo Nikolajeva e Scott (2011) tanto o texto verbal como o texto visual possuem algumas lacunas. Ambos os elementos podem se complementar, fechando essas lacunas de maneira total ou parcial, assim como eles também podem criar lacunas para que o leitor complete. Palavras e imagens podem ser lidas tanto de maneira individual, quanto de maneira conjunta, adicionando níveis de complexidade a uma mensagem.

Podemos perceber então, que livro ilustrado, não se enquadra ao lado de termos como história de terror ou história de comédia e sim ao lado de termos como livro, peça de teatro, música, desenho e tantas outras linguagens através das quais construimos narrativas de diversos gêneros. $E$ que através do uso de duas linguagens diferentes, um livro ilustrado pode facilitar ou modificar o entendimento de uma narrativa ao adicionar mais um 
nível de complexidade além do verbal em suas construções narrativas.

Referências:

GOMES, Regina; MANCINI, Renata. Textosmidiáticos: uma introdução à semiótica discursiva.Atas do IX FELIN. Rio de Janeiro: UERJ, 2007.

NIKOLAJEVA, Maria; SCOTT, Carole. Livro ilustrado: palavras e imagens. São Paulo: CosacNaify, 2011.

PIETROFORTE, Antonio Vicente. Semiótica visual: os percursos do olhar. Editora Contexto,2004.

VAN DER LINDEN, Sophie. Para ler o livro ilustrado. Cosac Naify, 2011. 